\title{
Psychodynamic Methodology of Deep Perception of a Person's Mind
}

\author{
Tamara Yacenkoํ, Olena Polianychko², Oleksandra Pedchenko \\ ${ }^{1}$ Department Deep Correction and Psycho-Social Rehabilitation, The Bohdan Khmelnytsky National University of Cherkasy, Cherkasy, \\ Ukraine \\ ${ }^{2}$ Department of Physical Education, Borys Grinchenko Kyiv University, Kyiv, Ukraine \\ Email:ts_yacenko@mail.ru,o.polianychko@kubg.edu.ua
}

How to cite this paper: Yacenko, T., Polianychko, O. and Pedchenko, O. (2016) Psychodynamic Methodology of Deep Perception of a Person's Mind. Open Journal of Social Sciences, 4, 27-31. http://dx.doi.org/10.4236/jss.2016.412003

Received: November 10, 2016

Accepted: December 2, 2016

Published: December 6, 2016

Copyright (๑) 2016 by authors and Scientific Research Publishing Inc. This work is licensed under the Creative Commons Attribution International License (CC BY 4.0).

http://creativecommons.org/licenses/by/4.0/

\begin{abstract}
In the article "Psychodynamic methodology of deep perception of a person's mind" an issue is raised on methodology of forming competency in a future psychologist on the basis of adequate understanding of wholeness of the psychic; comparison of academic and psychodynamic approaches to the problem of academic training of a psychologist is done as well as analysis of the leading sects in psychology relevant to psychodynamic approach. There were introduced main positions of psychodynamic theory, which are accordant with orthodox psychoanalysis in the same way as the principles of psyche in its integrity. Content of the given article stresses the importance of taking into account interconnections between the spheres of the conscious and the unconscious in their integrity and functional asymmetry in deep psychocorrection of the future psychologists.
\end{abstract}

\section{Keywords}

Active Social-Psychological Perception (ASPP), Probabilistic Forecasting, Deep Correction, Deep Perception, Methodology, Objective-Subjective, Competency of a Psychologist, Psychodynamic Approach, Sense, Theory

\section{Introduction}

The way of forming competency in a future psychologist cannot stay out of methodol$o g y$, which involves not only mastering of theoretical knowledge by a future psychologist but also the practice of diagnostic and correction process in groups of active social-psychological perception (ASPP).

Psychodynamic paradigm aligns attention with the joint progress to the truth in an active interaction of a psychologist with a respondent (participant in the process of 
deep perception of the psyche). Ethical appropriateness of perception acquires the significance in the context of perception of the psyche in its integrity (conscious/unconscious). The purpose is defined only in general, like a guide of a psychodynamic process that is clarified in the dynamics of semantic appropriateness of the subject activity, progress of which becomes consistent with the objective logic of perception. These are positions that underlie psychodynamic approach to the training of a psychologist, overcoming a simplistic mechanistic view of the understanding of the subject of psychology. Psychodynamic theory (due to positive results of diagnostic and correction practices over years) evidenced that the psyche is whole in the presence of functional differences and autonomy of the conscious and unconscious spheres. Psychodynamic approach is based on the following: A holographic structure of the unconscious (thereby "psyche knows everything" and at the same time "it does not know what it knows"); involuntary activity of a subject (in which some elements of the psychic embody the essence of the whole), procedural diagnostics, which is the basis of deep perception. Empirical material persuades of the existence of internal functional arrangement of the psychic that has relevance to information equivalents, which combine both spheres of the psyche. The article states the continuity of information exchange between subsystems (conscious/unconscious), including the transfer of ideal (spiritual) reality into materialized not only into physiological ("brain"), but also into external subjectified, visualised one, which opens perspectives of deep perception according to laws of the conscious to a psychologist. That is why the process of deep perception in ASPP groups is invariably mediated by presenter (sculpturing, drawing, stone models, etc.) created by its participants.

Deep psychologist relies on the assumption of unity of the conscious and the unconscious, which focuses on the horizon of their contact, and not the line of their separation. The entire procedure of active social-psychological perception is aimed at objectification and restoration of damaged interconnections (information exchange) between substructures of the psyche that finds expression in subjectivism (distortion) of displaying activity of an individual and leads to social failures, maladaptation under pressure of consistence of objective reality. Subjectivism of psychic image is caused by objective (though ideal) reality of laws of functioning of the unconscious (i.e., other sphere), which manifests itself in the invariance of psychic characteristics generated by the defensive system. The latter give rise to the effect of possible predictability of behaviour by external observer (psychologist).

\section{Discussion and Suggestion}

Humanistic organizational principles of the process of active social-psychological perception contribute to levelling of contextual (peripheral) forms of psychological defence, opening the prospect of approaching the perception of basal forms of defence based on implied core values. Given the deep self-perception, a future expert surveys diagnostic and correction process in the "probabilistic forecasting" oriented to perception of behavioural material logical ordering. The latter facilitates detection of incon- 
sistency of energy direction of the "logic of the conscious" and the "logic of the unconscious" ("other logic") in the ASPP process [1]. The specificity of reliable logic of deep perception is due to the lack of capacity of complete elimination (reduction) of the probability. In other words, a factor of incomplete probability is invariably present in deep perception, with dynamics up to clarification of meanings of behavioural acts, in the direction from the field of the significance to the uniqueness.

Researches in psychodynamic format confirm the fact that the probabilistic logic is a kind of multiple-valued logic that is not limited to two-valued property ("true or false") only. The process of deep perception takes into account the availability of symbolism and its polyvaluedness. The latter implies the probability of the truth through the lack of a priori certainty of content (meaning) of spontaneous behaviour that can be overcome by batch supply of information to a respondent by a psychologist. Spontaneity of behaviour of one or another respondent is distinguished with the frequency of manifestations of iterative, invariant, repetitive behaviour patterns, having proximity to the concept of relative frequency by its content. Researches are also directed to an issue of statics and dynamics of organization of the psychical in the integrity of its functioning. In this context, the role is played by concepts such as disposition, setting, tendency, a dynamic stereotype that contribute to defining the vector of direction of an individual $s$ energy, depending on "mortido" or "libido".

Activity of the ASPP team leader is based on probabilistic assumptions of logical ordering of behavioural material, and rational-logical interpretations of diagnostic and correction process relate to an analysis of features of perception of spontaneous ("subjective") person's activity. The ability to prevent algorithmization of acts of a deep correction process leader is an integral part of both a general methodical strategy of the ASPP method and its partial methodologies, which are adjusted to current diagnostic and correction issues in the "here and now" situation. The latter corresponds to theoretical and methodological foundations of deep perception as well as a psychodynamic model of optimal diagnostic and correction, analytical and dialogue work of a psychologist with a respondent [2].

General personal changes in a future psychologist have been already set by group principles of work arrangement in ASPP groups: acceptance of other people (and yourselves) as they are; sincerity; an analysis of behaviour of other people (and self-analysis); a lack of criticism (and self-criticism); formation of skills "to be in the situation and be over it"; decentration of attention; overcoming the "tunnel vision" effect; transforming yourselves into a "research subject"; weakening both tendencies to own "psychic importing" and tendencies "towards psychological death" and so on.

Individual personal changes: dynamics of individualized development is catalysed by a process of positive disintegration and secondary integration of the psyche at the higher level of development, due to revealing its internal ordering detection and resolution of personal issues (inner contradictions) by a future psychologist, leading to harmonization of his/her psyche.

Personal professional changes correspond to general psychodynamic line of creative 
selection of working methods and tools to meet the needs of a deep process of "here and now" according to the individual psychical uniqueness of a particular person. The ASPP process encourages the development of empathy, sensitivity, intuition, selfanalysis skills (self-reflection) and longitudinal analysis (interpretation) of behaviour of other people. Development of abilities to procedural psychical diagnosis in its unity with correction takes place in a future psychologist during studies [3].

Personal growth generalized indicators of future applied psychologists as a result of ASPP groups: openness to new experiences; attention to acts of spontaneous behaviour of another person; prevalence of objectivity in assessing the conduct of another person on projective-emotional (subjectivized) assessment; social activity, adequacy and adaptability; weakening of stereotypes and automation of behaviour; reduction in depressive and regressive tendencies of behaviour; ability to reveal their own constructive potential, which implies reducing the mortido (destructive) energy and expanding the creativity horizons in the form of professional self-realization, etc.

So here are the conclusions. deep perception should have a mediated nature, visualization of primary "mediation" is desirable; materialized fixation of a "mediator" serves as an objective benchmark of perception; secondary mediation requires "revitalization" of self-presenter in the dialogic interaction (psychologist respondent); a process of dialogic interaction is carried out in a step-by-step, multi-level manner, with adherence to the rules of positive disintegration of the psychic and its integration at the higher level (through partial disintegration and integration); psychologist's questions are oriented to the internal implied ordering of the psychic, which is in synthesis with archetypal essence of the psychic; diagnostic capacity of questions (in terms of compliance with the internal ordering) generated an impulse in a person, a flow of energy that manifests itself in a person's motivation to both self-perception and the activity as a whole. $A$ dialogue is not aimed at establishing the personal relationships, but at the information exchange, all of which contribute to the interpretation and objectification of information equivalents potentially relevant to the psychic in its integrity [4].

Deep perception is aimed at revealing the meanings of these "manifestations" by their deployment in the temporal (time) characteristics.

\section{Conclusion}

Deep perception requires the consideration of the following: Specificity of functional interconnections in the integral psyche (conscious/ unconscious); energy activity of the sphere of the unconscious, manifestation of which is possible in minimizing (levelling) the external stimuli of the ASPP participants' activities in the situation of "here and now"; archetypal psychic capacity to self-objectification (sculpturing, drawings, etc.), with recoding the latent meanings into visualized form; mediation "mission" of a visualized presenter between the external and internal aspects of the psychic (conscious/ unconscious); nature of dialogic interaction of a psychologist with a respondent that promotes emotional "revitalization" of a presenter as a prerequisite for its transformation into a mediator; need to focus on the significance of the events experienced by a 
respondent shown in trace effects that define the impulse of responses of a respondent to question of a psychologist; differences between two aspects of psychic reality (conscious/unconscious): Their autonomy and inexistence apart from each other; need for probabilistic forecasting based on probability of interconnections, mutual transitions from the energy (unconscious) sphere into the semantically understandable as a result of interpretation (explanation); Information privacy of presenters, which stipulates the need for their decoding in dialogic interaction of a psychologist with a respondent.

\section{References}

[1] Yacenko, T.S. and Gluzman, A.V. (2015) Metodologia glubinnogo-korrekzionnoy podgotovki psihologa. T.S. Yacenko A.V. Gluzman. Dnepropetrovsk Izd-vo «Innovazia», 396.

[2] Yacenko, T.S. (2015) Dinamika razvitia glubinnou psihokorrekzii: Teoria i praktika: monografia. Dnepropetrovsk Izd-vo «Innovazia». 567.

[3] Yacenko, T.S., Polianychko, O.M. and Pedchenko, O.V. (2016) Metodologia glubinnogo poznania psihiki subekta. Nauchnuy gurnal Pedagogichnuy prozes:teoria i praktika. Kyiv. 23-30.

[4] Yacenko, T.S., Polianychko, O.M. and Pedchenko, O.V. (2016) Psihodinamicheskaia teoria i metodologia glubinnogo poznania psihiki subekta. Materialu VI migvidomchoi naukovo-praktuchnoi konferenzii Aktualni problemu psyhologichnoi dopomogu, sozialnoi ta medikopsuhologichnoi reabilitazii uchasnikov antiteroristichnoi operazii. Kyiv, 397-399.

Submit or recommend next manuscript to SCIRP and we will provide best service for you:

Accepting pre-submission inquiries through Email, Facebook, LinkedIn, Twitter, etc.

A wide selection of journals (inclusive of 9 subjects, more than 200 journals)

Providing 24-hour high-quality service

User-friendly online submission system

Fair and swift peer-review system

Efficient typesetting and proofreading procedure

Display of the result of downloads and visits, as well as the number of cited articles

Maximum dissemination of your research work

Submit your manuscript at: http://papersubmission.scirp.org/

Or contact jss@scirp.org 